\title{
Studies on larval parasitoids of Paranthrene tabaniformis (Rott.) (Lepidoptera: Sesiidae) on urban poplars (Populus spp.) in Sofia, Bulgaria
}

\author{
Georgi Georgiev* \\ Department of Forest Entomology and Phytopathology, Forest Research Institute, \\ 132, St. Kliment Ohridski Blvd., Sofia 1756, Bulgaria
}

(Received 25 January 1999; accepted 26 August 1999)

\begin{abstract}
Studies on the species composition and structure of the larval parasitoid complex of poplar clearwing moth, Paranthrene tabaniformis (Rott.), on urban poplars in Sofia and impact of different species on population density of the pest have been conducted during the period 1996-1999. P. tabaniformis larvae within poplar cuttings were collected from one-year-old poplar stumps in five residential areas in Sofia. Parasitoids were collected from pest damaged shoots in a laboratory. Ten larval parasitoids of the host were found: Bracon (B.) intercessor Nees, Macrocentrus (M.) marginator (Nees), Apanteles evonymellae (Bouché) (Hymenoptera: Braconidae), Liotryphon crassisetus (Thoms.), Scambus vesicarius (Ratz.), Lissonota culiciformis Grav., Dolichomitus sp., Pristomerus vulnerator (Panz.) (Hymenoptera: Ichneumonidae), Leskia aurea (Fall.) and Phytomyptera nigrina (Meig.) (Diptera: Tachinidae). The most numerous were A. evonymellae (70.1\%) and B. intercessor (16.3\%). They attacked young P. tabaniformis larvae and emerged at larval stage of the host. In 1996, the level of total parasitism in studied residential areas in Sofia varied from 12.1 to $46.6 \%$, with an average of $32.5 \%$. During the period $1997-1999$, mortality of the pest larvae caused by parasitoids reached $38.1-55.6 \%$. A. evonymellae was the most important parasitoid; it destroyed 23.8-55.6\% of pest larvae.
\end{abstract}

poplars / Paranthrene tabaniformis / parasitoids / host mortality / Bulgaria

Résumé - Parasitoïdes larvaires de Paranthrene tabaniformis (Rott.) (Lepidoptera : Sesiidae) dans les peupliers urbains de Sofia, Bulgarie. Entre 1996 et 1999, la composition spécifique et la structure du complexe parasitaire des larves de Paranthrene tabaniformis (Rott.) ont été étudiées dans les peupliers urbains de Sofia (Bulgarie) de même que l'impact de ces parasitoïdes sur la densité de population du ravageur. Les larves de $P$. tabaniformis et leurs parasitoïdes ont été obtenues à partir de pousses de un an coupées sur des moignons de branches lors de l'abattage de vieux peupliers dans 5 quartiers résidentiels de Sofia («Slatina», «Druzhba», «Mladost», «Darvenitsa» et «Lyulin»), et placées au laboratoire. Dix parasitoïdes ont été trouvés : Bracon (B.) intercessor Nees, Macrocentrus (M.) marginator (Nees), Apanteles evonymellae (Bouché) (Hymenoptera : Braconidae), Liotryphon crassisetus (Thoms.), Scambus vesicarius (Ratz.), Lissonota culiciformis Grav., Dolichomitus sp., Pristomerus vulnerator (Panz.) (Hymenoptera : Ichneumonidae), Leskia aurea (Fall.) et Phytomyptera nigrina (Meig.) (Diptera : Tachinidae). Les parasitoïdes les plus abondants sont $A$. evonymellae $(69,1 \%)$, B. intercessor $(17,3 \%)$, P. vulnerator (3,6 \%), et Dolichomitus sp. (3,6 \%). Ce sont des parasitoïdes solitaires, à l'exception de B. intercessor qui est grégaire. B. intercessor, L. crassisetus, S. vesicarius et Dolichomitus sp. sont des ectoparasitoïdes; les autres sont des endoparasitoïdes. Ils attaquent les jeunes larves de P. tabaniformis et sortent de l'hôte

* Correspondence and reprints

Tel. 359262 2961; Fax. 359262 2965; e-mail: forestin@bulnet.bg 
alors que celui-ci est encore au stade larvaire. En 1996, le niveau de parasitisme total dans les quartiers résidentiels de Sofia a varié de 12,1 à 46,6 \%, avec une moyenne de 32,5\%. En 1997 et en 1999, la mortalité des larves du ravageur, due au parasitisme, a atteint 38,1-55,6 \%. A. evonymellae a eu l'impact le plus élevé, détruisant de 23,8 à 55,6\% des larves du ravageur.

peupliers / Paranthrene tabaniformis / parasitö̈des / mortalité de l'hôte / Bulgarie

\section{INTRODUCTION}

The poplar clearwing moth, Paranthrene tabaniformis (Rottemburg 1775), is one of the most dangerous pests of the poplars (Populus spp.) in many regions of the Palaearctic zone $[2,17,20]$. It is associated mainly with the seedlings in nurseries and young trees in poplar plantations. The pest causes serious malformations of the host plants. In Bulgaria damages occur most frequently in the nurseries, where attacks have been reported up to $40 \%$ of the poplar seedlings [6].

$P$. tabaniformis occurs as a pest not only in poplar nurseries and plantations, but also in urban systems. Damage by this insect has been observed periodically on the poplars in the streets and parks of Sofia [9]. The larvae bore galleries in the young shoots and branches of the trees. Infested host plants produce characteristic swellings and deformations, which result in strong aesthetic damages on ornamental trees.

In Bulgaria control of $P$. tabaniformis is usually achieved by treatments with systemic organophosphate insecticides and synthetic pyrethroids [6]. However, they are strongly toxic and their use in urban environment is dangerous. Supplementary control by using biological limiting factors of the pest, such as parasitoid would be helpful to reduce $P$. tabaniformis populations.

Some parasitoids regulate the population densities of the pests at a relatively low number, thus being one of the main factors for the sustainability of the ecosystems. The parasitoid complex of $P$. tabaniformis in Europe includes about 30 species from the families Ichneumonidae, Braconidae, Encyrtidae and Tachinidae which reduce the pest number in some cases up to $65 \%$ $[2,3,17$, etc.]. In Bulgaria, 15 species have been found as parasitoids of the pest and ten of them were reported as new records for its parasitoid complex: Bracon triangularis Nees (Hymenoptera: Braconidae), Scambus detritus Holm., Pristomerus rufiabdominalis Uchida, Dolichomitus messor (Grav.), Eriborus sp. (Hymenoptera: Ichneumonidae), Megaselia sp. (Diptera: Phoridae) [12], Phytomyptera nigrina (Meig.) (Diptera: Tachinidae) [14], Scambus vesicarius (Ratz.), Liotryphon crassisetus (Thoms.) (Hymenoptera: Ichneumonidae) [15], and Lissonota culiciformis Grav. (Hymenoptera: Ichneumonidae) [10]. Although large numbers of investigations have been carried out, no spe- cial studies on parasitoids of $P$. tabaniformis on poplar ornamental trees in urban areas have been made in Bulgaria or other countries.

The paper presents study on the species composition and structure of the larval parasitoid complex of $P$. tabaniformis in Sofia and their impact on pest numbers.

\section{MATERIALS AND METHODS}

The studies were conducted during the years 19961999 in 5 residential areas in Sofia - "Slatina", "Druzhba", "Mladost", "Darvenitsa" and "Lyulin". The biological materials (P. tabaniformis larvae within poplar cuttings of approximate $20 \mathrm{~cm}$ ) were collected from one-year-old poplar stump shoots at the place of cut down old poplars - unknown hybrid clones from euramericana-group, Populus $x$ euramericana (Dode) Guinier.

After collection, infested poplar cuttings were transported to the laboratory of the Forest Research Institute in Sofia, where sections were covered with paraffin, and each cutting was kept individually in a glass cylinder closed with cotton stoppers and kept at room temperature $\left(18-22^{\circ} \mathrm{C}\right)$. In this way the poplar cuttings are kept fresh for a long time, which allows most of the host larvae to complete their development. The samples were observed daily for emergence of adult hosts or parasitoids. The longevity of each individual was reported.

In 1996, population density of $P$. tabaniformis was relatively high $(0.1-0.7$ larvae/m), and seven collections of the pest larvae were made from March 3 to April 21 . During the period 1997-1999, the populations of $P$. tabaniformis were very low $(0.01-0.05$ larvae/m), and only 18 - 21 larvae were collected annually in March from one residential area. However, more damaged poplar shoots with $P$. tabaniformis larvae were collected and analysed during the period of study, but only in 370 cases parasitoids and hosts were observed - 311 in 1996, 18 in 1997, 21 in 1998, and 20 in 1999. In the rest of the samples the larvae died because the cuttings dried out. In this study the parasitism was calculated only on the bases of emerged parasitoids and hosts.

At the end of the observation period, the poplar cuttings were opened and their contents analyzed in detail 
in order to determine the cause of mortality of the host and to establish some bioecological characteristics of the parasitoids. Emerged parasitoids were killed with ethyl acetate, identified and deposited in the author's collection.

\section{RESULTS}

\subsection{Species composition and structure of the parasitoid complex}

Ten hymenopteran and dipteran larval parasitoids of $P$. tabaniformis were recorded in Sofia (table I). They belong to the two orders and three families as follows: Bracon (Bracon) intercessor Nees 1834, Macrocentrus (Macrocentrus) marginator (Nees 1812), Apanteles evonymellae (Bouché 1834) (Hymenoptera, Braconidae), Liotryphon crassisetus (Thomson 1877), Scambus vesicarius (Ratzeburg 1844), Lissonota culiciformis Gravenhorst 1829, Dolichomitus sp., Pristomerus vulnerator (Panzer 1799) (Hymenoptera, Ichneumonidae), Leskia aurea (Fallén 1820) and Phytomyptera nigrina (Meigen 1824) (Diptera, Tachinidae). M. marginator was described as new parasitoid of $P$. tabaniformis, and $L$. aurea and $B$. intercessor were reared for the first time from this host in Bulgaria (table I).
Most of the parasitoids were recorded in 1996 during an outbreak of $P$. tabaniformis. During the period 1997-1999 the pest density was low and resulted in the collection few partasitoids.

The relative abundance $(\%)$ of all braconids in the parasitoid complex of P. tabaniformis was $87.1 \%$. Ichneumonids made up $11.5 \%$, while tachinids were $1.4 \%$. The most abundant were two braconids - $A$. evonymellae $(70.1 \%)$ and B. intercessor $(16.3 \%)$, followed by the ichneumonids $P$. vulnerator $(3.4 \%)$ and Dolichomitus sp. (3.4\%), while the other species are presented by $0.7-2.7 \%$ (table I).

Structure of the parasitoid complex of $P$. tabaniformis in Sofia varied greatly from year to year and between different residential areas. Only A. evonymellae was recorded all four years and it was the dominant in the parasitoid complex of the pest with $62.5-100 \%$. In 1996 dominant species was B. intercessor (19.8\%) as well, but this status is due to the gregarious mode of its parasitism on the host. In the same year three species were subdominant $(P$. vulnerator $-4.1 \%$, Dolichomitus sp. $-4.1 \%$ and $S$. vesicarius $-3.3 \%$ ); the remaining parasitoids were not numerous.

Only separate parasitoid individuals were recovered in $1997(n=10), 1998(n=8)$ and $1999(n=8)$ and that is why it is not correct to analyze the species composition and structure of the parasitoid complexes.

Table I. Species composition, structure and impact of the parasitoids of $P$. tabaniformis in Sofia during the period 1996-1999.

\begin{tabular}{|c|c|c|c|c|c|}
\hline $\begin{array}{l}\text { Family, } \\
\text { species }\end{array}$ & \multicolumn{2}{|c|}{ Number of parasitoids } & $\begin{array}{l}\text { Emergence } \\
\text { date }\end{array}$ & $\begin{array}{l}\text { Percentage in } \\
\text { the complex }\end{array}$ & $\begin{array}{c}\text { Host mortality } \\
\%\end{array}$ \\
\hline Braconidae & 68 & 60 & 87.1 & & \\
\hline ** B. intercessor & 15 & 9 & $11-18.04 .1996$ & 16.3 & 1.3 \\
\hline \multirow[t]{2}{*}{ * M. marginator } & - & 1 & 12.04.1998 & 0.7 & 4.8 \\
\hline & 44 & 37 & 22.03-03.05.1996 & & 26.1 \\
\hline \multirow[t]{3}{*}{ A. evonymellae } & 6 & 4 & 25-29.03.1997 & 70.1 & 55.6 \\
\hline & 2 & 3 & $20-25.03 .1998$ & & 23.8 \\
\hline & 1 & 6 & 07-13.04.1999 & & 35.0 \\
\hline Ichneumonidae & 11 & 6 & & 11.5 & \\
\hline L. crassisetus & - & 1 & 02.04 .1996 & 0.7 & 0.3 \\
\hline S. vesicarius & 4 & - & 29.03-16.04.1996 & 2.7 & 1.3 \\
\hline L. culiciformis & - & 2 & 18.05 .1998 & 1.3 & 9.5 \\
\hline Dolichomitus sp. & 5 & - & 28.03-29.04.1996 & 3.4 & 1.6 \\
\hline P. vulnerator & 2 & 3 & 13-16.05.1996 & 3.4 & 1.6 \\
\hline Tachinidae & 2 & - & & 1.4 & \\
\hline P. nigrina & 1 & - & 09.05 .1996 & 0.7 & 0.3 \\
\hline ** L. aurea & 1 & - & 21.04.1999 & 0.7 & 5.0 \\
\hline Total & 81 & 66 & & 100.0 & \\
\hline
\end{tabular}

* - New species for parasitoid complex of P. tabaniformis.

** - New parasitoid of the host in Bulgaria. 


\subsection{Biological characteristics of the parasitoids}

All of the parasitoids attacked the larvae of $P$. tabaniformis were larval while no pupal parasitoids were recorded in this study. Analyses of dead hosts showed that parasitoid adults emerged from third - fifth larval instars prior to pupating.

$B$. intercessor was gregarious; an average $6.0 \pm 1.83$ $(n=4)$ adults were obtained per host. From the remaining hosts solitary parasitoids were recovered. Four species - B. intercessor, L. crassisetus, $S$. vesicarius and Dolichomitus sp. developed as ectoparasitoids, and the other species were internal parasitoids.

With the exception of $L$. culiciformis which emerged almost at the same time as the host, the remaining parasitoids emerged in laboratory 24-33 days prior to the emergence of $P$. tabaniformis and lived without additional feeding $1-8$ days.

\subsection{Impact of the parasitoids}

The total mortality of $P$. tabaniformis from larval parasitoid attacks in the studied areas ranged between 12.1 and $55.6 \%$

In 1996, total parasitism in studied residential areas in Sofia varied from 12.1 to $46.6 \%$, and the average was $32.5 \%$. In 1997 total parasitism of P. tabaniformis was $55.6 \%$, and in 1998 and $1999-38.1$ and $40.0 \%$, respectively.

During all four years, A. evonymellae was the most important parasitoid of $P$. tabaniformis, killing $23.8-55.6 \%$ of the pest larvae (table I).

The remaining parasitoids occurred in relatively low number and they were not important as regulating agents of the pest.

\section{DISCUSSION}

In many regions of Bulgaria $P$. tabaniformis develops one generation per year and overwinters as a larva in third - sixth (mostly in fifth) stage [7]. In the Sofia region $P$. tabaniformis usually overwinters in second fourth stage (Georgiev, unpublished). The samples were taken from the beginning of March until the end of April and, therefore, the parasitoids of the young and middlestage larvae of $P$. tabaniformis were studied in this investigation.

In Bulgaria A. evonymellae is the most common and most effective parasitoid of $P$. tabaniformis, which has been confirmed from this and other investigations [5,
12]. It occurs in all areas studied in Bulgaria [12]. In poplar nurseries it reduced the pest population by up to $35 \%$ [5]. A. evonymellae overwinters as a larva in the host. It is bivoltine, but only the second (overwintering) generation is associated with $P$. tabaniformis; in the spring the emergence of $A$. evonymellae is not synchronized with $P$. tabaniformis larval population and its premier generation develops in alternate hosts [8]. In the Netherlands this parasitoid has been reported to kill up to $55 \%$ of the $P$. tabaniformis larvae [16].

Eriborus terebrans (Grav.) (Hymenoptera: Ichneumonidae) parasitizes up to $39 \%$ of $P$. tabaniformis young larvae in some localities in Bulgaria, thus occupying a secondary position as a limiting biocontrol agent among the parasitoids [5]. It is known mainly as a parasitoid of European corn borer, Ostrinia nubilalis (Hb.) (Lepidoptera: Pyralidae) [21]. However, E. terebrans was not observed in Sofia, probably because of absence of its main host.

$P$. vulnerator kills up to $15 \%$ of $P$. tabaniformis larvae in the poplar nurseries in Bulgaria [5]. This parasitoid completes two generations per year in the larvae of Gypsonoma aceriana (Dup.) (Lepidoptera: Tortricidae) [11]. However, only the overwintering generation of $P$. vulnerator is connected with $P$. tabaniformis $[5,6,12]$; in the spring parasitoid adults appear about 20-25 days prior to emergence of $P$. tabaniformis and cannot attack its neonate larvae.

The new species for parasitoid complex of $P$. tabaniformis, $M$. marginator is known as a parasitoid of many lepidopteran hosts including clearwing moth species of Synanthedon genus: S. culiciformis (L.), S. vespiformis (L.), S. cephiformis (O.), S. formicaeformis (Esp.), S. myopaeformis (Borkh.), S. spheciformis (Den. \& Schiff.), S. tipuliformis (Cl.) [22]. L. crassisetus also parasitizes some representatives of this genus: $S$. flaviventris (Staud.), S. scoliaeformis (Borkh.), S. myopaeformis, S. culiciformis [4] and S. typuliformis [1].

B. intercessor (syn. B. fulvus Szepl.) has been previously recorded as a parasitoid of $P$. tabaniformis in Hungary $[18,19]$.

P. nigrina has been found as a parasitoid of $P$. tabaniformis only in Bulgaria [14]. The other species of Tachinidae family - L. aurea parasitizes species of Synanthedon genus - S. vespiformis, S. scoliaeformis, S. formicaeformis, S. typhiaeformis (Borkh.) [13] and $S$. myopaeformis [23]. This parasitoid has been recorded previously from other $P$. tabaniformis populations in Europe [17, 20]. It is bivoltine [23]; in this study its overwintering generation was associated with $P$. tabaniformis. 
During the years of investigation, parasitoids destroyed a significant portion (32.5-55.6\%) of overwintering larvae of $P$. tabaniformis in Sofia. No studies have been conducted on the parasitoids during the summer months, but in other habitats of the host in Bulgaria three species - Bracon mediator Nees, B. triangularis and $E$. terebrans reduced the number of the pest during the vegetation period up to $14 \%$ [5]. Therefore, it is possible that the mortality of $P$. tabaniformis caused by parasitoids in Sofia is actually higher.

Parasitoids of $P$. tabaniformis appear to be the major factor in maintaining a low pest population density in Bulgaria. They can be a promising tool in devising a strategy for management of the pest. Some its biological characteristics, such as freedom from any hyperparasitoids, appearance before the host, etc., can find a place for increasing of the beneficial impact of the parasitoids in poplar plantations. For example, it is well known that the most important parasitoids emerge about one month before $P$. tabaniformis in Bulgaria and if some pest control against other pests in this period is needed, it would be is advisable to use selective larval insecticides. In this way, the flying adult parasitoids will not be affected and can exert an additional impact on the pest. In the poplar nurseries the infested by xylophagous insects control is accomplished by burning the seedlings. However it would be better from a pest control perspective to preserve the cuttings with $P$. tabaniformis larvae in containers covered with plastic net which has mesh-openings $5 \times 5 \mathrm{~mm}$. The net will stop the pest moths from escaping but will let the parasitoid adults through. These measures might increase of the sustainability of the poplar stands.

In urban areas in Sofia the parasitoids are obviously important biological component in reducing the number of $P$. tabaniformis. Some of them are probably responsible for maintaining the pest populations at relatively low levels, thus being a contributing factor towards the improvement of the decorative value of young poplar ornamental trees.

Acknowledgements: I am grateful to Dr. J. Kolarov, Biological Faculty of "St. Kl. Ohridski" University in Sofia, for identifying of the species of Ichneumonidae, Dr. Z. Hubenov, Institute of Zoology at the Bulgarian Academy of Sciences, for identifying of the species of Tachinidae, and Dr. Kees van Achterberg, Nationaal Natuurhistorisch Museum - Leiden, the Netherlands, for identifying of Bracon intercessor Nees. I also thank Dr. F. Herard and Dr. F. Vega, European Biological Control Laboratory, Montpelier, France, and Dr. B. Binder, Department of Agriculture, Agricultural Research Service, Iowa, USA, for their critical reading and revising of the English language version of the manuscript.

\section{REFERENCES}

[1] Aubert J.F., Les ichneumonides ouest-paléarctiques et leurs hôtes. 1. Pimplinae, Xoridinae, Acaenitinae, OPIDA, 1969.

[2] Bertucci B., Il tarlo vespa del pioppo, Inform. fitopatol. 11 (1986) 29-34.

[3] Ceianu I., Radoi D., Constantinescu E., Paranthrene tabaniformis Rott. Cercetari cu privirela biologie si combatre, Centrul de documentare tehnica pentru economia forestiera (in Romanian) 1967.

[4] Fitton M.G., Shaw M.R., Gauld I.D., Handbook for the Identification of British Insects. Hymenoptera, Ichneumonidae (Pimplinae), Royal Entomological Society of London, 1988.

[5] Georgiev G., The role of parasitoids in regulating the frequency of poplar clearwing moth, Paranthrene tabaniformis (Rottemburg 1775) (Lepidoptera: Sesiidae) in Bulgaria, in: "70 years forestry education in Bulgaria", part 3, Sofia (in Bulgarian, English summary) 1995, pp. 383-390.

[6] Georgiev G., The poplar clearwing moth [Paranthrene tabaniformis (Rottemburg, 1775), Lepidoptera: Sesiidae] biology, ecology and possibilities for controlling it in North Bulgaria, Ph.D. Thesis, Forest Research Institute - Sofia, 1995 (in Bulgarian).

[7] Georgiev G., Phenology of the poplar clearwing moth (Paranthrene tabaniformis Rott., Lepidoptera: Aegeriidae) in Northern Bulgaria, For. Sci. 1 (1995) 60-67 (in Bulgarian, English summary).

[8] Georgiev G., Notes on the biology and ecology of the parasitoids of the poplar clearwing moth, Paranthrene tabaniformis (Rott.) (Lepidoptera: Sesiidae) in Bulgaria, I. Apanteles evonymellae (Bouché 1834) (Hymenoptera, Braconidae) J. Appl. Ent. (in press).

[9] Georgiev G., Delkov A., Phytophagous insects and their parasitoids on poplar trees in Sofia, Acta Entomol. Bulg. 1-2 (1997) 61-65 (in Bulgarian, English summary).

[10] Georgiev G., Kolarov J., New Ichneumonidae (Hymenoptera) parasitoids on forest insect pests in Bulgaria, Anz. f. Schädlingsk. 72, 3 (1999) 57-61.

[11] Georgiev G., Samuelian S., Species composition, structure and impact of larval parasitoids of poplar twig borer, Gypsonoma aceriana (Dup.) (Lepidoptera, Tortricidae), on poplar ornamental trees in Sofia, Anz. f. Schädlingsk. 72, 1 (1999) 1-4.

[12] Georgiev, G., Tsankov, G., Some parasitoid insect species on the larvae of the poplar clearwing moth (Paranthrene tabaniformis Rott., Lepidoptera: Sesiidae) in Bulgaria, For. Sci. 2 (1995) 51-58 (in Bulgarian, English summary).

[13] Herting B., Biologie der westpalaarktischen Raupenfliegen Dipt., Tachinidae, Monographien zur angew. entomologie 16 (1960) 188. 
[14] Hubenov Z., Georgiev G., Phytomyptera nigrina (Meig.) (Diptera, Tachinidae) - new parasitoid on poplar clearwing moth (Paranthrene tabaniformis Rott.) (Lepidoptera, Sesiidae), For. Sci. 4 (1996) 87-89 (in Bulgarian, English summary).

[15] Kolarov J., Georgiev G., New Pimplinae (Hymenoptera, Ichneumonidae) parasitoids of poplar clearwing moth (Paranthrene tabaniformis Rott., Lepidoptera: Sesiidae), For. Sci. 1/2 (1997) 130-134 (in Bulgarian, English summary).

[16] Moraal L.G., Evaluation of infestations by the poplar clearwing moth, Paranthrene tabaniformis Rott., in: Proceedings of the 20th Session of the International Poplar Commission, part 1, Budapest, 1996, pp. 250-259.

[17] Postner M., Familienreihe Aegeridoidea, in: Schwenke W. (Ed.), Die Forstschädlinge Europas. 3 Band, Schmeterlinge. Paul Parey, Hamburg und Berlin, 1978, pp. 188-205.
[18] Szontagh P., A Paranthrene tabaniformis Rott. hazai életmódja és károsítasa, Állatt. közl. 52 (1-4) (1965) 135-142 (in Hungarian).

[19] Szontagh, P., Adatok a Paranthrene tabaniformis Rott. (Lepidoptera) fejlodesi es parasitaltsagi viszonyaihoz, Folia Ent. Hung. 24, 7 (1971) 99-108 (in Hungarian).

[20] Templado, J., Paranthrene tabaniformis Rott., importante plaga del chopo, Publs. Inst. Biol. Apl. 37 (1964) 33-52.

[21] Townes H., Momoi S., Townes M., A catalogue and reclassification of the eastern palearctic ichneumonidae, Mem. of the American entomological institute 5, 1965.

[22] Tobias V., Insect Key for the European part of USSR, part 3 (4), Nauka, Leningrad, 1986 (in Russian).

[23] Tschorsnig H.-P., Herting B., The Tachinids (Diptera: Tachinidae) of Central Europe: Identification Keys for the species and Data on distribution and Ecology, Stuttgarter Beiträge zur Naturkunde, Serie A (Biol.) 506 (1994) 170. 